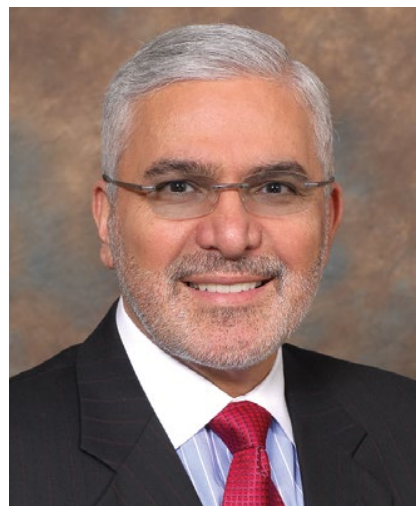

Henry A. Nasrallah, MD Editor-in-Chief doi: 10.12788/cp.0151

\title{
From ideology to articles of faith: The 'religification' of political beliefs
}

Man is a political animal.

-Aristotle

Politics, Book 1, Section 1253 a

\section{Religion is the opium of the people.}

-Karl Marx,

A contribution to the critique of Hegel's philosophy of right, introduction

\section{The toxic hyper-} partisanship that has dominated the United States may be the culmination of an intensified 'religification' of politics
Beliefs are at the core of psychiatric practice. Our patients are often shackled by their anomalous beliefs, which are not reality-based. These beliefs are often the primary targets of psychiatric treatment. Consider a day at the office of a psychiatrist who may see several patients impaired by false beliefs, such as:

- My neighbor is reading my mind remotely and is plotting to kill me

- If I ride on a plane, it will crash and I will die

- I am a failure, a worthless person, and a burden on my family

- I am hopeless and helpless; life is too painful and not worth living anymore

- I am a prophet with supernatural gifts, and I can predict the future

- Whenever I take this substance, I feel I can jump out of a window and fly

- If I do not shower 5 times in a row every night before going to bed, something terrible will happen to my family.

Patients with false beliefs obviously need psychiatric care. However, a large

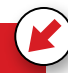

number of religious individuals harbor "unusual" beliefs involving angels and devils and hell and paradise after death. Those people of faith are not considered to have a DSM-5 psychiatric disorder. Billions of people around the world belong to one of the approximately 4,300 religions, which they celebrate using one of the more than 6,800 living languages. Psychiatrists encourage patients to have a faith because it can be quite comforting to its adherents, enhancing their social relations and providing them with hope and resilience during the darkest days of life. Regular attendance at a house of worship is a measure of the strong roots of one's faith.

So why have there been so many religious wars over centuries of recorded history? Why have millions of people died during conflicts among religions? Why does one religious group adamantly believe that theirs is the real God, while the god of other religions is fake? And why have people who withdrew from or refused to adopt a certain religious belief been persecuted; labeled as "heretic," "infidel," "heathen," or "apostate"; and burned at the stake or beheaded? Perhaps religion is not always a kinder, gentler belief system.

Recent statistics show a precipitous decline in religious observance in the United States. ${ }^{1}$ So what happens to a society that gradually abandons its 


\section{Table}

\section{Similarities between religion and politics}

\begin{tabular}{ll} 
Religion & Politics \\
\hline Articles of faith & Ideology or doctrine \\
\hline Demonizes the devil & Demonizes the opposition party \\
\hline Differences trigger wars & Responsible for declaring wars \\
\hline Criticizes political beliefs & Criticizes religious beliefs \\
\hline Belief in a "god" & Belief in a "leader" \\
\hline Infighting within sects & Infighting between moderates and radicals \\
\hline Antipathy to other religions & Hatred towards other political parties \\
\hline Can be politicized & Can be religified \\
\hline Dogmatic belief system & Dogmatic belief system \\
\hline Fervor and zealotry & Fanaticism and extremism \\
\hline Excommunicates dissidents & "Cancels" the dissidents \\
\hline Inquisition for nonbelievers & Special prosecutors for "the other side" \\
\hline Solicits donations & Solicits contributions \\
\hline Infused with moral tenets & Driven by legal principles \\
\hline Fraught with corruption and scandals & Saddled with corruption and scandals \\
\hline
\end{tabular}

previously entrenched religious beliefs and becomes secular? This trend is spreading widely in Europe and North America. But widely held beliefs with powerful personal meaning don't just fizzle away: they re-emerge in another form. The substantial energy of religious faith must be invested elsewhere and manifested in an alternative form with similar dynamics.

\section{Enter politics!}

It seems that humans' need to uphold a strong belief is so powerful that they either incorporate political doctrines side-by-side with their religious beliefs (if the 2 are compatible) or adopt a strong political belief if they abandon their religion and become secular. This does not have to be an intellectually wrenching change because there are many similarities between hyper-religiosity and fanatic political beliefs (Table).

The toxic hyperpartisanship that has dominated the United States over the past several years may be the culmination of an intensified "religification" of politics. The incendiary mix of religious zealotry and political fanaticism is conducive to intensified loathing, hostility, and animus to those with an opposing political ideology.

So it all boils down to the human imperative of harboring a strong personal belief. What is the origin of beliefs, religious, political, or otherwise? Why does the human species have the overwhelming need to uphold a belief? Research suggests that it is the result of evolution and the phylogenetic enlargement of the brain, including the parietal and medial frontal cortex in humans. ${ }^{2}$ And according to many studies, abnormal and delusional beliefs encountered in psychiatric practice appear to be caused by altered perception and/or misattribution of aversive meaning. ${ }^{3}$ Lesions in the right hemisphere have been reported to play an important role in generating delusional beliefs. ${ }^{4} \mathrm{~A}$ healthy right hemisphere plays an important role in:

- pragmatic communications

- perceptual integration

- attentional surveillance and anomaly novelty detection

- belief updating. ${ }^{4}$
Editorial Staff

EDITOR Jeff Bauer

SENIOR EDITOR Sathya Achia Abraham ASSISTANT EDITOR Matthew Wyles

WEB EDITOR Kathryn Wighton

Art \& Production Staff

CREATIVE DIRECTOR Louise Koenig

ART DIRECTOR Pat Fopma

DIRECTOR, JOURNAL MANUFACTURING Michael Wendt

PRODUCTION MANAGER Donna Pituras

Publishing Staff

PUBLISHER Sharon Finch

DIRECTOR EBUSINESS DEVELOPMENT Alison Paton

SENIOR DIRECTOR OF SALES

Tim LaPella

Editor-in-Chief Emeritus

James Randolph Hillard, MD

Frontline Medical Communications VP, SALES Mike Guire

VP, DIGITAL CONTENT \& STRATEGY Amy Pfeiffer

PRESIDENT, CUSTOM SOLUTIONS JoAnn Wahl

CIRCULATION DIRECTOR Jared Sonners

In affiliation with Global Academy for Medical Education, LLC

PRESIDENT David J. Small, MBA

\section{FRONTLINE MLedge}

7 Century Drive, Suite 302

Parsippany, NJ 07054

Tel: (973) 206-3434

Fax: (973) 206-9378

www.frontlinemedcom.com

Subscription Inquiries: subscriptions@mdedge.com

Published through an educational partnership with lé CINCINNATI 
Right hemispheric pathology disrupts those functions and can lead to false beliefs such as delusions, or, on a milder scale, strongly held superstitions.

One wonders how the structure and function of the right hemisphere generates and perpetuates a belief in a religion or political ideology that ultimately shapes one's life. Religiosity and politics are an inherent part of human nature, and they can replace each other or merge together. If one is to believe what Durkheim ${ }^{5}$ proposed more than a century ago, the existence of belief systems is essential for societal stability. He posited that the absence of stable belief systems can lead to what he labeled "anomie," leading to a surge of suicide and crime. If that is true, then the coexistence of religious and political beliefs may have a significant upside, but also with a palpable downside when either or both of those belief systems become excessively antagonistic or extreme. Three cheers for religious and political moderation that allows them to peacefully coexist.

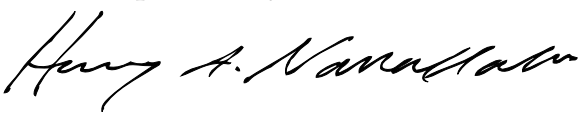

Henry A. Nasrallah, MD

Editor-in-Chief

References

1. Jones JM. U.S. church membership falls below majority for first time. Gallup. March 29, 2021. Accessed June 7, 2021. https://news.gallup.com/ poll/341963/church-membership-falls-belowmajority-first-time.aspx

2. Seitz RJ, Angel HF. Belief formation-a driving force for brain evolution. Brain Cogn. 2020;140:105548. doi: 10.1016/j.bandc.2020.105548

3. Seitz RJ. Beliefs: a challenge in neuropsychological disorders. J Neuropsychol. 2021. doi: 10.1111/jnp.12249

4. Gurin L, Blum S. Delusions and the right hemisphere: a review of the case for the right hemisphere as a mediator of reality-based belief. J Neuropsychiatry Clin Neurosci. 2017;29(3):225-235. doi: 10.1176/appi. neuropsych. 16060118

5. Durkheim E. Suicide: a study in sociology. The Free Press; 1951.
Religiosity and politics are an inherent part of human nature, and they can replace each other or merge together 